\title{
Distribusi Frekuensi Fraktur Gigi Permanen di Rumah Sakit Gigi dan Mulut Universitas Muhammadiyah Yogyakarta
}

\author{
Frequency Distribution of Permanent \\ Tooth Fractures in Dental Hospitals \\ of Muhammadiyah University of \\ Yogyakarta
}

\author{
Wustha Farani ${ }^{1}$, Wasi'a Nurunnisa ${ }^{2}$ \\ ${ }^{1}$ Dosen Program Studi Kedokteran Gigi FKIK UMY \\ ${ }^{2}$ Mahasiswa Program Studi Kedokteran Gigi FKIK \\ UMY \\ Korespondensi: drg_wustha@yahoo.com
}

\begin{abstract}
Traumatic dental injuries can affect people of all ages ranging from children, adolescents, adults, and the elderly. Traumatic dental injuries can affect of hard dental tissues and periodontal tissues in oral cavity. Each country has a different frequency of injuries each year. Traffic accidents often occur in developing countries, this is the most common cause of dental fracture. The purpose of this study was to determine the frequency of dental fractures that often occur.

The type of this research is descriptive observational with cross sectional design. The subjects consisted of 114 patients at RSGM UMY. This data collection uses secondary data of patients in 2016.

Based on the data obtained were analyzed using Statistical Package for Science (SPSS). Data processing used descriptive statistics to determine the frequency and percentage of dental fractures in the age, sex, etiology and type of teeth involved.
\end{abstract}

Keywords: distribution of traumatic frequency, classification of Ellis \& Davey

\begin{abstract}
Abstrak
Cedera dapat mengenai di berbagai kalangan usia mulai dari anak-anak, remaja, dewasa, dan lansia. Cedera dapat mempengaruhi pada jaringan keras dan jaringan pendukung di rongga mulut. Setiap negara memiliki frekuesi cedera yang berbeda-beda setiap tahunnya. Di Negara berkembang sering terjadi kecelakaan lalu lintas, hal ini menjadi penyebab paling umum fraktur gigi. Tujuan penelitian ini adalah untuk mengetahui frekuensi fraktur gigi yang sering terjadi.

Jenis penelitian ini adalah observasional deskriptif dengan desain cross sectional. Subyek penelitian terdiri dari 114 pasien di RSGM UMY. Pengambilan data menggunakan data sekunder pasien di tahun 2016.

Berdasarkan data yang diperoleh dianalisis menggunakan Statistical Package for Science (SPSS). Pengolahan data menggunakan statistik deskriptif untuk mengetahui frekuensi dan persentase fraktur gigi pada kelompok usia, jenis kelamin, etiologi dan jenis gigi yang terlibat.
\end{abstract}

Kata kunci: distribusi frekuensi trauma, klasifikasi Ellis \& Davey 
Wustha Farani, Wasi'a Nurunnisa | Distribusi Frekuensi Fraktur Gigi Permanen di Rumah Sakit Gigi dan Mulut Universitas Muhammadiyah Yogyakarta

\section{PENDAHULUAN}

Indonesia merupakan negara berkembang, di negara berkembang kecelakaan lalu lintas adalah penyebab paling umum terjadinya trauma ${ }^{1}$. Dalam praktik dokter gigi dapat dijumpai beberapa kasus cedera. Mereka datang dengan berbagai macam cedera pada jaringan keras atau gigi maupun jaringan pendukungnya ${ }^{2}$. Traumatic Dental Injuries (TDI) sebagai penyebab terjadinya fraktur. Trauma gigi merupakan sebuah kasus yang mempunyai tingkat prevalensi relatif tinggi. Pada dasarnya setiap negara memiliki prevalensi trauma gigi dengan jumlah yang berbeda - beda setiap tahunnya ${ }^{3}$.

Trauma gigi dapat mengenai di berbagai kalangan usia mulai dari anak-anak, remaja, dewasa, dan lansia ${ }^{4}$. Prevalensi trauma gigi berdasarkan usia di Nigeria, 146 pasien yang berusia 16 hingga 78 tahun didapatkan kejadian trauma tertinggi terjadi dikelompok usia 2534 tahun dengan persentase $40,4 \%$ sejumlah 59 pasien, sedangkan pasien yang memiliki persentase terendah yaitu kelompok usia lebih dari 65 tahun sebesar $4,8 \%^{2}$. Frekuensi trauma gigi pada anak usia 8 hingga 12 tahun didapatkan hasil usia 9 tahun memiliki persentase tertinggi sebesar 47,37\%, diikuti dengan usia 10 tahun sebesar $24,56 \%$, dan yang terendah pada usia 11 tahun sebesar 7,02\% ${ }^{5}$. International Association Dental Traumatology melaporkan usia anak yang sering terjadi trauma antara usia 8 dan 12 tahun $^{6}$.
Berdasarkan jenis kelamin, laki - laki memiliki potensi trauma gigi lebih besar dibandingkan perempuan. Perbandingan kejadian trauma gigi dari jenis kelamin laki laki dengan perempuan adalah $2: 1^{7}$. Frekuensi terjadinya fraktur gigi anterior berdasarkan jenis kelamin pada pasien dewasa, laki - laki sebesar $76(53,1 \%)$ dan $67(46,9 \%)$ untuk perempuan. Hasil tersebut menunjukan laki - laki memiliki frekuensi terjadinya fraktur gigi lebih tinggi dari pada perempuan ${ }^{8}$.

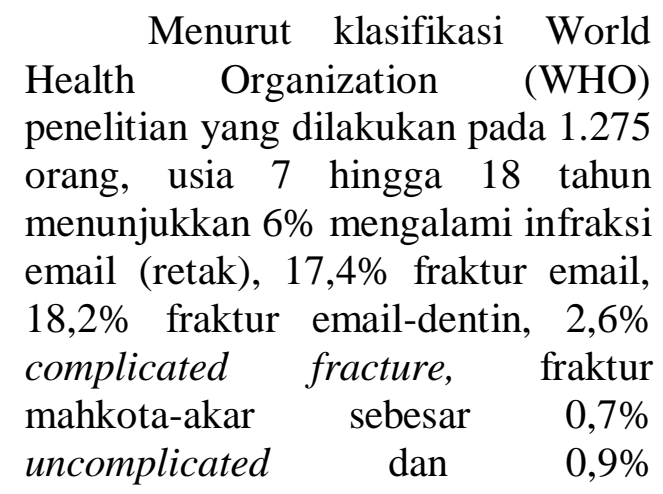
complicated, fraktur $1 / 3$ servical sebesar $0,3 \%, 1 / 3$ bagian tengah (middle) 0,6\%, dan 1/3 apikal 0,3\% ${ }^{7}$. Hasil penelitian di Turkey distribusi trauma gigi sehubungan waktu cedera dengan waktu perawatan darurat pada fraktur email-dentin relatif tinggi. Pada gigi sulung terdapat 145 kasus sedangkan gigi permanen 229 kasus. Data tersebut menunjukan hasil yang lebih besar dibandingkan dengan fraktur email ${ }^{9}$.

Berdasarkan penelitian di Targu Mure, Romania frekuensi jenis trauma gigi sulung dan permanen tertinggi pada insisivus sentral maksila sebesar 55,3\%, insisivus lateral maksila $28 \%$, kaninus maksila $5,8 \%$, insisivus sentral mandibula $4,3 \%$, insisivus lateral mandibula $2,4 \%$, dan kaninus mandibula $1 \%$. 
Beberapa penelitian menunjukkan bahwa gigi anterior insisivus sentral maksila yang memiliki trauma tertinggi ${ }^{10}$. Pada gigi posterior cenderung mengalami fraktur vertikal. Prevalensi tertinggi yaitu gigi premolar kedua rahang atas $(27 \%)$ dan gigi molar $(25 \%)^{11}$.

Terdapat beberapa klasifikasi antara lain klasifikasi World Health Organization (WHO) berdasarkan jaringan keras, jaringan periodontal, tulang pendukung, dan gingiva atau oral mucosa ${ }^{3}$. Selain klasifikasi World Health Organization (WHO), terdapat klasifikasi Ellis dan Davey membagi menjadi 9 kelas yang terdiri dari kelas 1 hingga kelas 8 untuk gigi permanent sedangkan kelas 9 untuk gigi sulung ${ }^{12}$.

Fraktur gigi terbagi menjadi dua yaitu fraktur longitudinal yang sering terjadi pada semua tipe gigi dan fraktur horizontal pada gigi anterior. Penyebab kasus fraktur longitudinal disebabkan oleh prosedur dental dan tekanan oklusal, seperti akibat dari kebiasaan mengunyah es, permen keras, karies yang merusak kekuatan gigi dan preparasi kavitas yang berlebihan ${ }^{13}$. Sedangkan etiologi dari fraktur horizontal terbagi menjadi trauma gigi yang tidak disengaja, trauma gigi yang disengaja dan iatrogenik TDI. Trauma gigi yang tidak disengaja meliputi jatuh, benturan, kegiatan fisik seperti olahraga, kecelakaan lalu lintas, penggunaan gigi yang tidak tepat, menggigit benda yang keras, adanya penyakit seperti epilepsy dan keterbatasan fisik. Adapun trauma gigi yang disengaja seperti kekerasan fisik. Sedangkan iatrogenik TDI yang sering terjadi seperti kerusakan mahkota atau bridges, avulsi hingga nekrosis pulpa ${ }^{3}$.

Upaya pencegahan trauma
gigi sangat diperlukan oleh
masyarakat, dalam hal ini upaya
yang dapat dilakukan yaitu
meningkatkan pendidikan atau
pengetahuan dan pengasuhan dari
orang tua $^{14}$.

Oleh karena itu, penulis ingin memberikan gambaran mengenai kejadian fraktur email dentin tanpa pulpa terbuka di Rumah Sakit Gigi dan Mulut Universitas Muhammadiyah Yogyakarta (RSGM-UMY). Rumah sakit ini menyediakan perawatan kesehatan gigi, sehingga terdapat kasus - kasus mengenai fraktur gigi dari berbagai kalangan usia.

\section{METODE}

Penelitian ini merupakan observasional deskriptif dengan menggunakan desain cross sectional, penelitian ini dilakukan untuk mengetahui frekuensi terjadinya fraktur email dentin tanpa pulpa terbuka pada gigi permanen di RSGM UMY tahun 2016.

Jenis data penelitian ini menggunakan data sekunder yang didapatkan dari rekam medis pasien yang telah dilakukan pemeriksaan klinis oleh dokter gigi muda di RSGM UMY. Kriteria inklusi penelitian adalah pada gigi permanen pasien di RSGM UMY periode tahun 2016. Kriteria ekslusi penelitian adalah gigi karies, dentinogenesis imperfecta dan displasia dentin. 
Wustha Farani, Wasi'a Nurunnisa | Distribusi Frekuensi Fraktur Gigi Permanen di Rumah Sakit Gigi dan Mulut Universitas Muhammadiyah Yogyakarta

Tahapan yang dilakukan dalam penelitian ini dimulai dari pengumpulan data, selanjutnya analisis data menggunakan Statistical
Package for Science (SPSS) version 17 pengolahan data deskriptif dalam bentuk frekuensi dan persentase.

\section{HASIL PENELITIAN}

Penelitian ini dilakukan di RSGM UMY periode tahun 2016 dengan jumlah 114 pasien yang mengalami fraktur Ellis kelas 2 dan terdapat 148 kasus yang telah memenuhi kriteria inklusi.

Tabel 1. Distribusi frekuensi fraktur gigi berdasarkan jenis kelamin dan usia

\begin{tabular}{lllllll}
\hline $\begin{array}{l}\text { Usia } \\
\text { (tahun) }\end{array}$ & Laki - laki & \multicolumn{3}{c}{ Perempuan } & $\mathrm{N}$ & $\%$ \\
\hline $6-11$ & 13 & $\%$ & $\mathrm{~N}$ & $\%$ & & \\
$12-16$ & 14 & $11,4 \%$ & 12 & $10,5 \%$ & 25 & $21,9 \%$ \\
$17-25$ & 35 & $12,3 \%$ & 6 & $5,3 \%$ & 20 & $17,5 \%$ \\
$26-35$ & 4 & $30,7 \%$ & 26 & $22,8 \%$ & 61 & $53,5 \%$ \\
$46-55$ & 1 & $3,5 \%$ & 2 & $1,8 \%$ & 6 & $5,3 \%$ \\
\hline Jumlah & 67 & $0,9 \%$ & 1 & $0,9 \%$ & 2 & $1,8 \%$ \\
\hline
\end{tabular}

Tabel 1. menunjukan frekuensi terjadinya fraktur gigi pada jenis kelamin laki-laki dan perempuan yang memiliki nilai tertingi yaitu usia 17-25 tahun. Cenderung mengalami penurunan pada usia dewasa hingga lansia. Pasien jenis kelamin laki-laki memiliki nilai terjadinya fraktur gigi lebih besar dari pada perempuan.

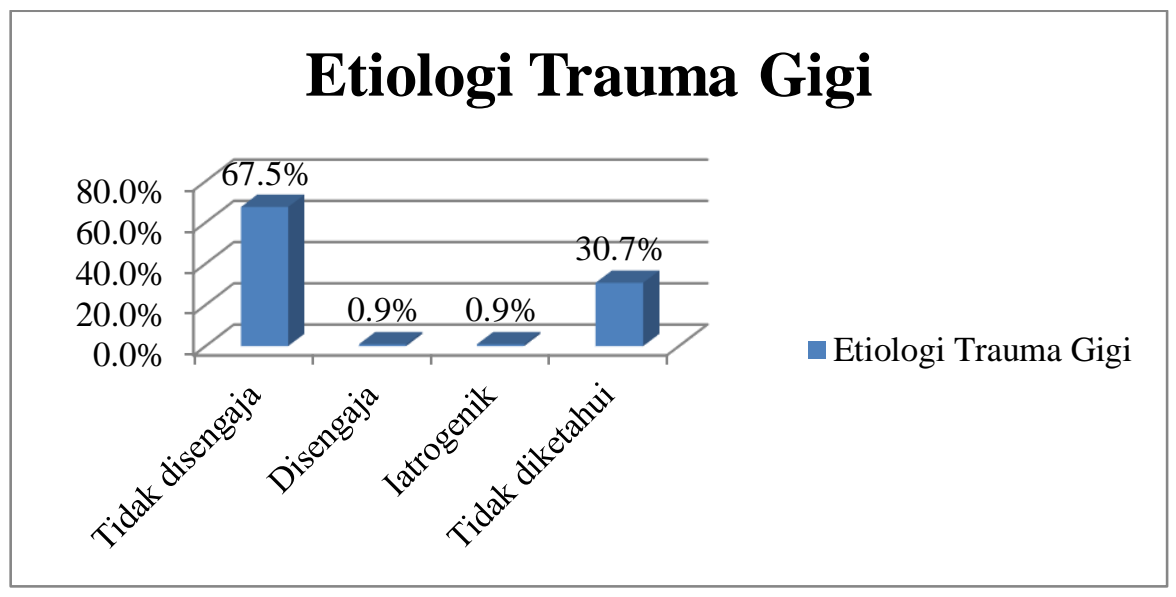

Gambar 1. Distribusi frekuensi etiologi trauma gigi permanen

Gambar 1. menunjukan frekuensi etiologi trauma gigi tertinggi akibat tidak disengaja sebesar $67,5 \%$. Etiologi disengaja dan iatrogenik memiliki frekuensi terendah sebesar $0,9 \%$, sedangkan yang tidak diketahui atau tanpa keterangan sebesar $30,7 \%$. 


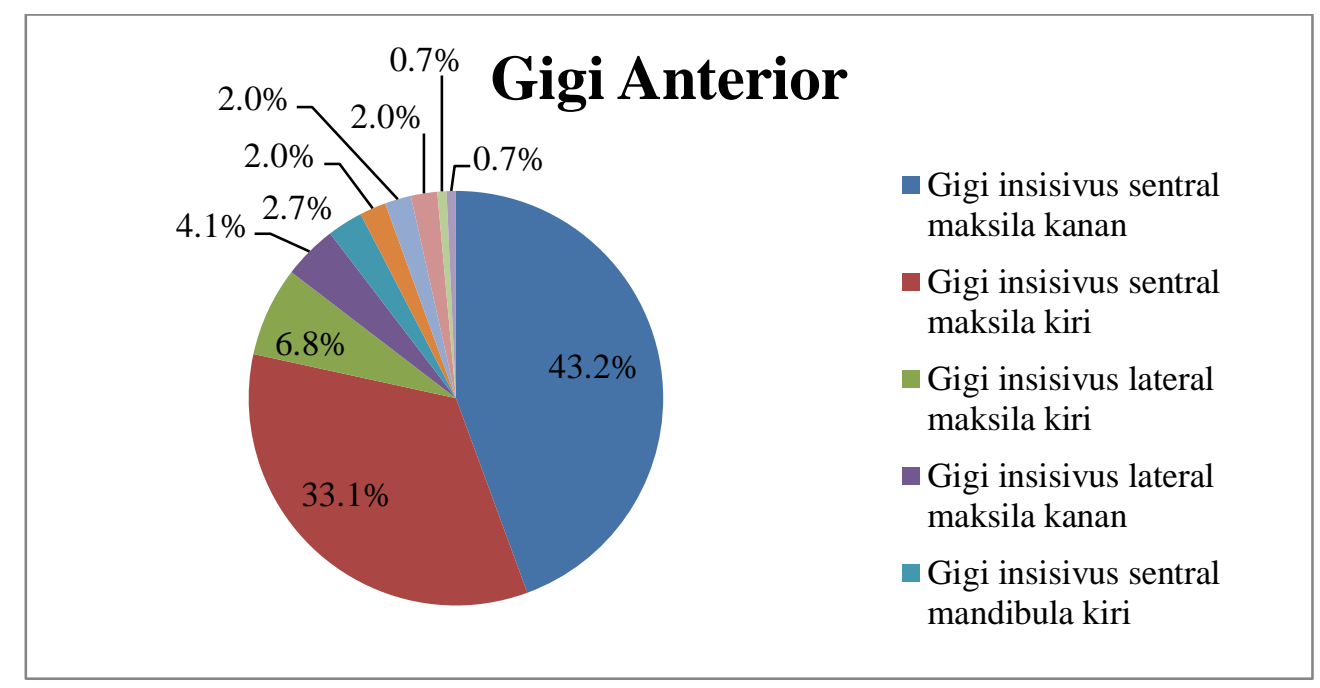

Gambar 2. Distribusi frekuensi fraktur Ellis kelas 2 pada gigi anterior

Gambar 2. menunjukan hasil fraktur gigi anterior memiliki frekuensi total sebesar 97,3\%. Gigi anterior yang sering terjadi fraktur gigi yaitu gigi insisivus sentral maksila kanan sebesar 43,2\%. Diikuti dengan gigi insisivus sentral maksila kiri sebesar $33,1 \%$. Pada gigi insisivus lateral maksila kiri memiliki frekuensi sebesar $6,8 \%$ dan $4,1 \%$ pada gigi insisivus lateral maksila kanan. Frekuensi fraktur tertinggi gigi rahang bawah yaitu gigi insisivus sentral mandibula kiri sebesar 2,7\%. Gigi insisivus lateral mandibula kiri, gigi insisivus sentral mandibula kanan, dan gigi insisivus lateral mandibula kanan mempunyai frekuensi yang sama dengan persentase 2,0\%. Sedangkan gigi rahang atas dengan kedudukan frekuensi terendah sebasar $0,7 \%$ yaitu gigi caninus maksila kiri dan caninus mandibula kanan. 
Wustha Farani, Wasi'a Nurunnisa | Distribusi Frekuensi Fraktur Gigi Permanen di Rumah Sakit Gigi dan Mulut Universitas Muhammadiyah Yogyakarta

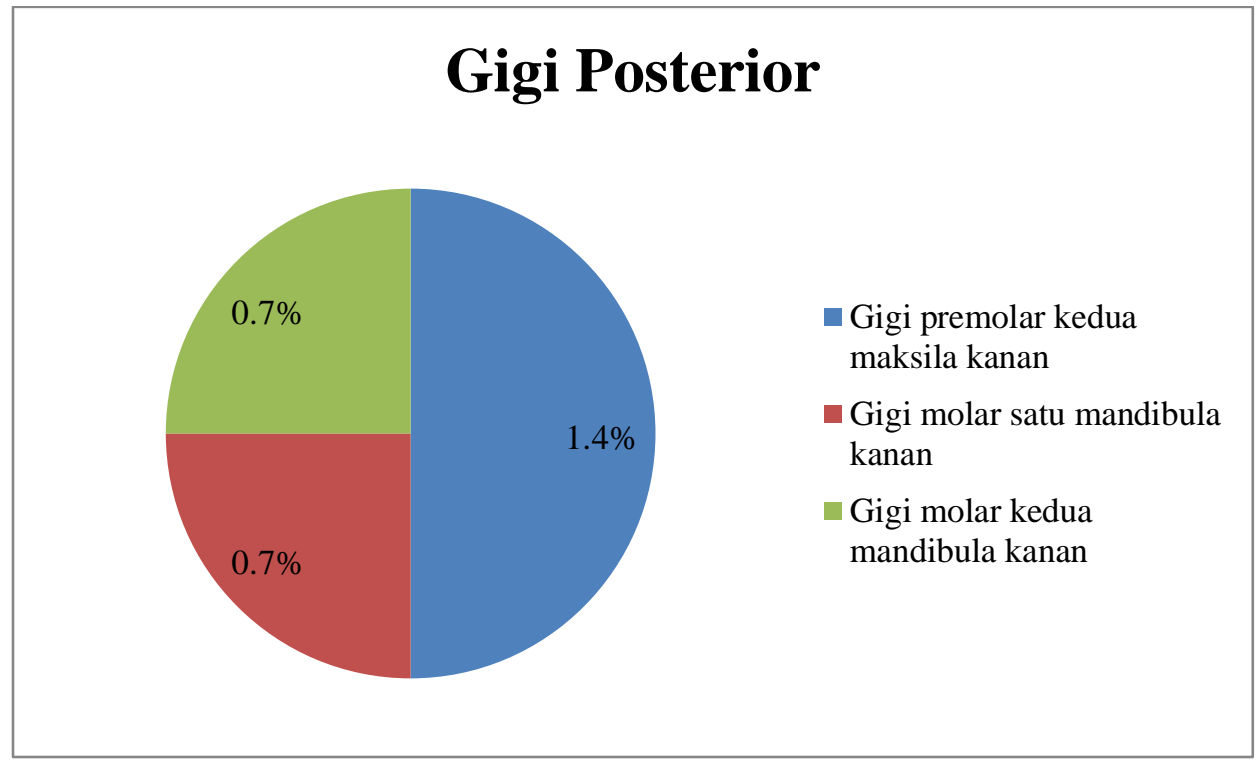

Gambar 3. Distribusi frekuensi fraktur Ellis kelas 2 pada gigi posterior

Gambar 3. menunjukan Total frekuensi fraktur gigi posterior hanya sebesar $2,7 \%$ yaitu gigi premolar kedua maksila kanan $1,4 \%$ dan $0,7 \%$

\section{PEMBAHASAN}

Berdasarkan hasil Penelitian didapatkan kejadian fraktur Ellis kelas 2 di tahun 2016 sejumlah 114 pasien dengan 148 kasus. Kasus fraktur Ellis kelas 2 di RSGM UMY memiliki jumlah kasus yang lebih tinggi dari pada kelas yang lain. Penelitian lain menyatakan jenis trauma yang sering terjadi umumnya yaitu fraktur email dentin lebih tinggi daripada fraktur mahkota komplit \& gigi avulsi. Fraktur email dentin akan cenderung memiliki rasa sensitivitas gigi, sehingga mendorong mereka untuk mengobati ${ }^{15}$.

Frekuensi fraktur gigi tertinggi pada usia 17-25 tahun dengan total persentase $53,5 \%$. Dalam kategori umur menurut Depkes (2009) usia 17-25 tahun gigi molar satu mandibula kanan serta gigi molar kedua mandibula kanan.

termasuk dalam kategori remaja akhir. Remaja lebih sering terjadi trauma dan akan mengalami penurunan pada usia lebih dari 30 tahun $^{3}$. Pasien dewasa yang mengalami fraktur gigi akan konsultasi kedokter gigi dengan alasan estetika buruk akibat trauma serta perubahan warna pada gigi, diikuti adanya rasa sakit ${ }^{2}$. Usia 21-30 tahun atau kategori dewasa akan lebih banyak melakukan aktivitas fisik dan perilaku yang berisiko dibandingkan dengan usia $>40$ tahun cenderung relatif berkurang aktivitas fisik dan lebih sedikit melakukan perilaku yang beresiko ${ }^{15}$. Sesuai dengan penelitian ini usia 46-55 tahun atau kategori lansia memiliki frekuensi terendah hanya sekitar $1,8 \%$. 
Frekuensi terjadinya fraktur gigi berdasarkan jenis kelamin pada laki - laki dengan persentase 58,5\% lebih tinggi daripada perempuan yaitu sebesar $41,2 \%$. Anak laki - laki akan cenderung lebih aktif daripada perempuan, sehingga mempunyai resiko lebih tinggi terhadap trauma ${ }^{3}$.

Etiologi yang sering terjadi pada penelitian ini akibat tidak disengaja dengan persentase $67,5 \%$. Sedangkan etiologi disengaja dan iatrogenik hanya $0,9 \%$. Etiologi tidak disengaja meliputi jatuh, benturan, kegiatan fisik seperti olahraga, kecelakaan lalu lintas, penggunaan gigi yang tidak tepat, dan menggigit benda yang keras. Iatrogenik merupakan penyebab dari kesalahan operator dan etiologi disengaja meliputi kekerasan fisik ${ }^{3}$. Etiologi trauma gigi mempunyai keterkaitan dengan usia pasien, dimana pada anak-anak penyebab utama fraktur gigi kebanyakan disebabkan karena jatuh dan olahraga. Berbeda dengan remaja atau dewasa biasanya karena kecelakaan lalu lintas. Seperti di negara berkembang, kecelakaan lalu lintas adalah penyebab paling umum terjadinya trauma ${ }^{1}$.

Jenis gigi anterior permanen yang banyak mengalami fraktur yaitu

\section{KESIMPULAN}

Berdasarkan hasil penelitian yang dilakukan, dapat disimpulkan bahwa:

1. Jumlah pasien yang melakukan pemeriksaan di RSGM UMY periode tahun 2016 pasca mengalami fraktur gigi sebesar 114 pasien dan terdapat 148 kasus fraktur Ellis kelas 2. gigi insisivus sentral maksila kanan sebesar $43,2 \%$ diikuti dengan gigi insisivus sentral maksila kiri sebesar $33,1 \%$. Sesuai dengan penelitian yang lain bahwa gigi anterior permanen anak-anak yang sering mengalami fraktur yaitu gigi insisivus sentral maksila kanan dan kiri. Hal ini dikarena gigi insisivus sentral maksila secara anatomis lebih protusif dibandingkan gigi yang lain sedangkan insisivus pada mandibula lebih sedikit terjadi trauma karena hubungan mandibula non rigid dengan basis crani yang memungkinkan akan terjadi gerakan fleksibel $^{5}$. Fraktur gigi permanen pada pasien dewasa menunjukan hasil yang sama dengan hasil penelitian ini ${ }^{15}$.

Gigi posterior memiliki frekuensi lebih rendah dari pada gigi anterior yaitu sebesar 2,7\%, meliputi gigi premolar kedua maksila kanan, gigi molar satu mandibula kanan, dan gigi molar dua mandibula kanan. Trauma gigi posterior biasa terjadi saat mastikasi, selain itu usia mempengaruhi kekuatan fisiologis gigi. Kelompok usia > 45 tahun lebih rentan terhadap fraktur gigi karena proses penuaan dan perubahan kekuatan fisiologis dari gigi $^{2}$

2. Frekuensi fraktur Ellis kelas 2 berdasarkan jenis kelamin yaitu laki-laki yang mengalami fraktur gigi sebanyak 67 pasien, sedangkan perempuan sebanyak 47 orang. Sehingga frekuensi farktur gigi pada laki-laki lebih besar dibandingkan perempuan.

3. Fraktur Ellis kelas 2 berdasarkan usia yang memiliki frekuensi 
Wustha Farani, Wasi'a Nurunnisa | Distribusi Frekuensi Fraktur Gigi Permanen di Rumah Sakit Gigi dan Mulut Universitas Muhammadiyah Yogyakarta

tertinggi pada rentang usia 17-25 tahun yaitu sebanyak 61 orang $(53,5 \%)$.

4. Berdasarkan etiologi trauma gigi yang sering terjadi yaitu akibat faktor tidak disengaja dengan persentase $67,5 \%$. Etiologi tidak disengaja meliputi jatuh, kecelakaan, benturan, kegiatan fisik, dan menggigit benda yang keras.

5. Jenis gigi yang sering mengalami cedera yaitu pada regio anterior, dimana gigi insisivus sentral maksila kanan memiliki nilai tertinggi dengan persentase 43,2\%. Diikuti gigi insisivus sentral maksila kiri sebanyak $33,1 \%$.

\section{DAFTAR PUSTAKA}

1. Andersson, L. (2013). Epidemiology of traumatic dental injuries. JOE, 39 (38). S2-S5.

2. Ajayi, D.M., Abiodun-Solanke, I.M., Sulaiman, A.O., \& Ekhalufoh E.F. (2012). A retrospective study of traumatic injuries to teeth at a Nigerian tertiary hospital. Journal of Clinical Practice, 15 (3). 320325.

3. Andreasen, J.O., Andreasen, F.M., \& Andersson, L. (2007). Traumatic injuries to the teeth (4 ${ }^{\text {th }}$ ed.). Denmark: A Blackwell Munksgaard.

4. Kademani, D. \& Tiwana, P (2016). Atlas of oral \& maxillofacial surgery. China: Elsevier Saunders.

5. Ikaputri, A., Sutadi, H., \& Fauziah, E. (2014). Distribusi frekuensi trauma gigi permanen anterior pada anak usia $8-12$ tahun. Jurnal Kedokteran Gigi.
6. McDonald, R., Avery., \& Dean. (2011). Dentistry for the child and adolescent ( $9^{\text {th }}$ ed). Mosby Elsevier

7. Koch, G. \& Poulsen, S. (2003). Pediatric dentistry. Oxford: Blackwell Munksgaard.

8. Enabulele J.E \& Mohammed B.E., (2017). Socio-demographic distribution of adult patients who seek oral health treatment following trauma to anterior teeth. J Trauma Care, 3 (1). 1017.

9. Unal, M., Oznurhan, F., Kapdan, A., Aksoy, S., \& Dürer, A. (2014). Traumatic dental injuries in children. Experience of a hospital in the central Anatolia region of Turkey. European Journal of Paediatric Dentistry, 15 (1). 17-22.

10. Kovács, M., Pãcurar, M., Petcu, B., \& Bukhari, C. (2012). Prevalence of traumatic dental injuries in children who attended two dental clinics in Târgu Mure between 2003 and 2011. OHDM, 11 (3). 116-124.

11. Loomba, K., Loomba, A., Bains, R., \& Bains, V., (2010) A proposal for classification of tooth fractures basedon treatment need. Journal of Oral Science, 52 (4). 517-529.

12. Rao, A. (2012). Principles and practice of pedodontics (3rd ed). India: Jaypee

13. Walton, R.E. \& Torabinejad, M. (2008). Prinsip dan praktik ilmu endodonsia $\quad\left(3^{\text {rd }}\right.$ ed.) (N. Sumawinata, penerjemah). Jakarta: EGC. (2001).

14. Cameron, A.C. \& Widmer, R.P. (2008). Handbook of pediatric dentistry ( $3^{\text {rd }}$ ed.). USA: Mosby Elsevier. 
Insisiva Dental Journal, Vol. 7 No. 1 Bulan Mei Tahun 2018

15. Enabulele, J.E., Oginni, A.O.,

Nigerians and complications Sede, M.A., \& Oginni, F.O. (2016). Pattern of traumatised from late presentation. BMC Res anterior teeth among adult 